\title{
The Moral Economy of the Peasant
}

REBELLION AND SUBSISTENCE

IN SOUTHEAST ASIA

James C. Scott

New Haven and London, Yale University Press 
Copyright $\odot 1976$ by Yale University.

All rights reserved.

This book may not be reproduced, in whole or in part, including illustrations, in any form (beyond that copying permitted by Sections 107 and 108 of the U.S. Copyright Law and except by reviewers for the public press), without written permission from the publishers.

Library of Congress catalog card number 75-43334

International standard book number: 978-0-300-02190-5 (paperbound)

Designed by John O. C. McCrillis and set in Baskerville Roman types. Printed in the United States of America.

The paper in this book meets the guidelines for permanence and durability of the Committee on Production Guidelines for Book Longevity of the Council on Library Resources.

23 
For Mia, Aaron, and Noah 
This page intentionally left blank 